\title{
0 Mercado Sobe o Morro. A Cidadania Desce? Efeitos Socioeconômicos da Pacificação no Santa Marta*
}

\author{
Sabrina Ost $t^{1}$ \\ Sonia Fleury ${ }^{2}$ \\ ${ }^{1}$ Fundação Getulio Vargas, Rio de Janeiro, Brasil \\ 'Escola Brasileira de Administração Pública e de Empresas da Fundação Getulio Vargas \\ (EBAPE/FGV), Rio de Janeiro, Brasil
}

\section{INTRODUÇÃO}

\begin{abstract}
A o longo da história, o Rio de Janeiro assistiu à expansão descontrolada das favelas como consequência da alteração entre a invisibilidade desta questão na agenda e políticas públicas de negação, repressão e remoção. A partir do século XIX (Valladares, 2000), quando a favela deixa de ser invisível para o poder público, ela passa a ser vista como um problema social, alimentada pela precariedade destas aglomerações urbanas consideradas subnormais e pelos mitos da marginalidade de suas populações (Perlman, 1981). A favela vista como problema retorna repetidamente à agenda política ao longo da história mais pelo incômodo que gera para a cidade do que pela perspectiva da assistência social (Zaluar e Alvito, 2006).

A fragilidade dos direitos nas favelas, bem como em outros loteamentos irregulares, é apontada como facilitadora da entrada do comércio de drogas e posterior domínio armado do território por facções de ban-

\footnotetext{
* O presente artigo é fruto da dissertação intitulada O Mercado Sobe a Favela: Um Estudo sobre o Santa Marta pós-UPP, de Sabrina Ost. Este trabalho foi um dos resultados do projeto Cidadania e Discriminação como Critérios de Análise da Política Pública, do Programa de Estudos sobre a Esfera Pública (PEEP), coordenado pela professora Sonia Fleury. Uma versão anterior deste artigo foi apresentada no XXXVI Encontro da Associação Nacional de Pós-Graduação e Pesquisa em Administração (EnANPAD), em 2012.
}

DADOS - Revista de Ciências Sociais, Rio de Janeiro, vol. 56, no-3, 2013, pp. 635 a 671. 
didos. À ausência de bens públicos e de políticas voltadas para a melhoria de vida dos favelados somou-se a persistência de um padrão de ilegalidade tais como os "gatos" de eletricidade e TV a cabo, e que inicialmente aceitava o tráfico de drogas como mais uma atividade ilegal, preço até então a ser pago pelos favelados para assegurar sua permanência (Fischer, 2008). Ironicamente, a redução das práticas repressivas após a redemocratização facilitou que essa fosse acompanhada pela maior presença e domínio do tráfico armado, o que fez desse território um espaço marcado pela permanente precariedade da ordem estatal, do mercado e da condição de cidadania a um patamar de barbárie sem precedentes. Vulnerabilidades, precariedades, informalidades e violências marcaram, a partir de então, o cotidiano das populações nas favelas com permanentes incursões policiais que resultavam em tiroteios e vítimas fatais e feridos. Um imaginário de uma "cidade partida" foi sendo construído, opondo a favela aos bairros, como se a separação social plasmada espacialmente indicasse uma situação de exterioridade e distanciamento cada vez mais intransponíveis. Mesmo que os dados corroborem essa diferença socioespacial, "a separação entre favela e não-favela expressaria a segmentação do acesso aos recursos localizados desigualmente na cidade, sejam eles os relativos à moradia ou às oportunidades de trabalho e renda" em um ciclo que se autoperpetua, já que os favelados que alcançam romper esse padrão buscam inserção em outros bairros da cidade (Ribeiro e Lago, 2001:153).

O crescimento da violência urbana passa a ser a gramática que articula um conjunto de práticas sociais e estrutura um padrão de sociabilidade que Machado da Silva denominou "sociabilidade violenta", no qual a força física, com ou sem instrumentos e tecnologias, deixa de ser um meio de ação para se transformar em um regime de ação (Machado da Silva, 2010). A exacerbação da violência assim socialmente autorizada terminou por debilitar tanto a cidadania quanto o Estado e o mercado, tornando-se uma ameaça potencial ao desenvolvimento urbano e regional.

Mais recentemente, mudanças nas políticas urbanas e de segurança, embora descontínuas, indicaram uma nova perspectiva voltada para a integração das favelas à cidade, motivados pela expectativa de realização de eventos internacionais na cidade. Antecederam as políticas atuais, que tomaram o nome de Unidades de Polícia Pacificadora (UPP), um conjunto de iniciativas e programas descontinuados de intervenção urbana em favelas e loteamentos, bem como transformações incre- 
mentais nas políticas de formação de pessoal e coordenação da área de segurança pública. Além disso, políticas sociais de recuperação do valor do salário mínimo com forte impacto redistributivo por meio dos benefícios previdenciários foram a marca dos últimos governos nacionais. Combinados com transferências condicionadas de renda para combate à pobreza e políticas assistenciais de saúde da família e de assistência social, esse conjunto de medidas, ainda que de forma não integrada, terminou por convergir para o espaço e populações localizadas nas favelas. O aumento do poder aquisitivo das populações nesses territórios favoreceu o aumento do consumo e o interesse mercadológico em relação a esses territórios.

As evidências de que as políticas redistributivas no campo do trabalho, saúde, previdência e assistência social tiveram um impacto econômico considerável na dinamização do mercado interno e no enfrentamento da crise econômica global terminaram por chamar a atenção de autoridades políticas e lideranças empresariais para o potencial de consumo das camadas mais pobres da população urbana, que passou a ser denominada de nova classe média (Neri, 2010), parte dela localizada nas favelas e loteamentos periféricos.

No campo da intervenção urbana o Programa Favela-Bairro, desenvolvido na década de 1990, voltou-se para a urbanização das favelas e foi seguido por outras iniciativas políticas similares de diferentes níveis governamentais, mesmo que limitadas ao aspecto urbano. Mais recentemente, o programa federal Programa de Aceleração do Crescimento (PAC) quando aplicado às favelas busca enfrentar conjuntamente questões de urbanização e a precariedade das moradias nesses territórios. Já a política de segurança pública do atual governo do Estado do Rio de Janeiro, que tem como principal pilar o policiamento comunitário por meio da implantação de Unidades de Polícia Pacificadora (UPP), de certa forma se inspira em experiências descontinuadas de policiamento comunitário implementadas no passado, como a Delegacia Legal, o Destacamento de Policiamento Ostensivo (DPO), o Posto de Policiamento Comunitário (PPC) e, mais recentemente, o Grupamento de Policiamento em Áreas Especiais (GPAE). Políticas do governo federal, como o Programa Nacional de Segurança Pública com Cidadania (Pronasci), também reforçaram esta linha que busca introduzir o componente de cidadania e respeito aos direitos humanos na formação e abordagem policiais, além de buscar uma coordenação entre os componentes do sistema de segurança pública. 
Assim, apesar das descontinuidades e incapacidade das políticas pretéritas de darem conta dos problemas da urbanização, habitação, saneamento e segurança nas favelas, elas serviram como subsídio para a formulação da atual política de pacificação, indicando uma perspectiva incremental de aprendizagem institucional e formação de consensos e alianças, necessários à mudança de rumo das políticas tradicionais de abordagem da favela. Por outro lado, a atual política pública de segurança visa romper com algumas características das políticas anteriores que demonstraram ser prejudiciais, como a não permanência do efetivo nas comunidades, que se tornou essencial quando a ação prioritária passou a ser a retomada do território pelo domínio estatal, já que o comércio ilegal de drogas passou a deter forte poderio bélico e controle sobre a população e o território.

Além do conjunto de microrreformas gerenciais na área de segurança que antecederam as UPPs, sem quebrar o padrão de ação anterior, dois fatores são apontados como responsáveis pela ruptura que essa política representa: por um lado, a autonomia operacional que o governador concedeu à Secretaria de Segurança a partir de 2007, e, por outro lado, a abertura de um canal direto do governo estadual com os empresários e acadêmicos reunidos em Thinks Tanks ${ }^{1}$ nos quais essa política foi formulada (Ferreira, 2011). É inovadora a forte articulação desta ação governamental com a atuação de grupos empresariais que participam diretamente no planejamento e execução desta política com diferentes ações, desde a formulação até o seu financiamento direto. A expectativa é que possam se beneficiar por meio da integração de áreas estrategicamente situadas nas zonas mais cobiçadas pelo mercado imobiliário, em uma cidade que vive um clima de euforia com sua inserção na economia dos eventos globais. Se esta articulação entre governo e empresariado é vista por alguns como virtuosa, permitindo a troca constante de percepções e o aumento das fontes de financiamento (ibidem), corre o risco de romper o padrão de processo decisório transparente e participativo, ambicionado nos modelos de controle social e cogestão, criados a partir da Constituição Federal de 1988, e que deveriam resultar em um Plano Diretor da Cidade democraticamente negociado.

A possibilidade de compatibilizar, nesses territórios, ações governamentais no campo da segurança, necessárias para o crescimento do mercado e aumento de atividades empresariais, com a expansão da condição de cidadania, foi a questão que nos mobilizou a pesquisar esta dinâmica em um caso concreto. 
A política atual de pacificação, implementada por meio das UPPs, permite observar como está se dando o redesenho destas relações em um dado território desde a perspectiva do fortalecimento do Estado pela recuperação do domínio territorial e do poder de coerção, o que permite a expansão dos negócios locais, além de contar também com ações empresariais de promoção social e de apoio às políticas públicas de desenvolvimento social. Os efeitos destas sinergias e novas modalidades de ação pública sobre a comunidade devem ser observados desde a perspectiva de assegurar a cidadania, considerando tanto a garantia de direitos e incremento de capacidades, assim também tomando como parâmetro o respeito às demandas comunitárias no desenho e execução das políticas.

A produção acadêmica acerca dos efeitos da atual política pública de segurança nas favelas tem sido intensa, e pesquisas recentes têm produzido um conjunto de dados sobre a expansão do mercado nesses territórios. Contudo, o aspecto da interação da população da favela com o mercado, de como esta dinâmica expansionista está afetando a vida das pessoas que lá habitam tem sido menos estudado, por ser mais recente. Buscamos, portanto, iniciar o preenchimento dessa lacuna ao focarmos nossa pesquisa na primeira favela pacificada, em dezembro de 2008, o Santa Marta ${ }^{2}$. Essa escolha se deu por considerarmos que o tempo transcorrido desde a sua implantação é razoável para que o mercado local respondesse aos impactos dessa política pública, bem como já é possível perceber novas interações dos atores do mercado externo com a comunidade, alteradas pela maior inserção do Estado. Ademais, o Santa Marta tem sido visto por estudiosos e até pelos moradores como comunidade vitrine/modelo do novo ordenamento. Por ser considerada uma comunidade de pequeno porte, já que ali habitam em torno de cinco mil pessoas ${ }^{3}$, e por estar localizada em área nobre e por ter sido a primeira a receber uma UPP, torna-se naturalmente uma forte candidata a atuação e intervenções pioneiras de diversos atores, inclusive de pesquisadores.

Neste estudo de caso da favela Santa Marta, o objetivo foi lançar luz sobre esse arranjo da política pública a partir de como a nova realidade está sendo vivida pela população local. Assim, buscamos identificar como as relações entre Estado, mercado e comunidade têm sido alteradas na favela Santa Marta após a implantação da UPP, especialmente focalizando como essa rearticulação tem sido vivenciada pelos moradores. É lugar comum a constatação de que a atuação estatal na área 
(seja ela policial, assistencial ou promocional) permitiu a expansão do mercado e gerou novas possibilidades e tensões em relação às garantias cidadãs devido às ameaças de remoção e à elevação do custo de vida. Esse processo, contraditório por si, já justifica o estudo de caso da comunidade onde foi implantada a primeira UPP.

Para tanto, foi realizada na favela Santa Marta uma pesquisa de campo que teve início em meados de outubro de 2011 e estendeu-se até meados de dezembro do mesmo ano. OSanta Marta é marcado pela presença e atuação de atores sociais importantes, como lideranças do Grupo ECO (Sociedade de Educação e Promoção Cultural), associação comercial, associação de moradores e rádio comunitária. Como outras favelas, possui um histórico de mutirões para construção de escadarias, casas, distribuição de água, e de mobilizações que se perderam ao longo do tempo. Para Itamar Silva, intelectual e liderança local, essa desmobilização se deve à satisfação das necessidades básicas, o que deixa as pessoas mais tranquilas e menos motivadas a buscarem outras melhorias (Pandolfi e Grynszpan, 2003).

A coleta de dados ${ }^{4}$ foi feita por meio de 15 entrevistas semiabertas com lideranças da favela e com moradores que se destacam na comunidade pela atividade empreendedora que realizam. Outras três entrevistas foram realizadas com representantes de atores do mercado (Sebrae, Firjan e Light), além de observações participantes em atividades festivas, guiamento turístico, bares, restaurantes, Fórum da UPP Social na favela e em reunião do Grupo $\mathrm{ECO}^{5}$. Os dados foram examinados utilizando-se análise de conteúdo, sob um viés qualitativo.

Assim, a partir da implantação da política pública de segurança na favela Santa Marta, analisamos a expansão do mercado na favela, no que tange à inserção de empresas externas a ela, bem como à diversificação e formalização de empreendimentos endógenos. Os efeitos causados nas relações sociais da comunidade foram estudados com base nas ações de agentes de mercado identificadas como responsabilidades sociais empresariais, desenvolvimento de capacidades e na ocorrência de formas de mercantilização dos espaços sociais. Estas novas dinâmicas foram percebidas pelos moradores tanto como geradoras de mais reconhecimento e potencialidades, como também provocando inseguranças em relação ao futuro da comunidade, vista como o elemento mais frágil no jogo de forças mencionado. As limitações inerentes à incapacidade de generalização de estudo feito a partir de um caso po- 
dem ser compensadas pelas claras indicações de problemas percebidos pela população na implantação da política pública das UPPs, cujo conhecimento pode servir para que as autoridades governamentais façam ajustes nos rumos desta política, de forma a buscar um arranjo virtuoso entre Estado, mercado e comunidade.

Este artigo está organizado em três seções adicionais. Na próxima seção, apresentamos a discussão teórica que fundamenta a análise da rearticulação entre Estado, mercado e comunidade. Na seção seguinte, os dados são agrupados nas categorias de expansão do mercado e promoção social. A expansão do mercado foi vista através das empresas que sobem o morro, da diversificação dos negócios e da formalização das relações de consumo de serviços. Já a promoção social foi tratada a com base nos programas de responsabilidade social e desenvolvimento de capacidades. As consequências dessa dinâmica para a vida dos moradores também foi analisada por meio da mercantilização dos espaços sociais e das inseguranças em relação à sustentabilidade da política e capacidade de resistência à remoção branca ${ }^{6}$. Na terceira e última seção apresentamos as considerações finais, apontando as contradições em relação à busca de expansão da cidadania por meio da ampliação do mercado.

\section{ESTAD0, MERCADO E CIDADANIA}

Karl Polanyi (1980) argumenta que o desenvolvimento do Estado moderno se deu de forma paralela e contraditória ao desenvolvimento da sociedade de mercado, porém ao mesmo tempo estiveram intimamente ligados. Esse processo se deu por meio de um duplo movimento: de um lado, houve a expansão do mercado; de outro, a ampliação do poder estatal no sentido de evitar que a dinâmica do mercado levasse ao desmoronamento da sociedade. Mecanismos de regulação e de proteção social levaram a um re-equacionamento da interação do mercado com a sociedade, cujos valores se materializaram em um conjunto de direitos e deveres assegurados por meio de políticas e instituições estatais.

Para Charles Lindblom (1982), o equívoco de Polanyi foi não ter percebido até que ponto o sistema de mercado aprisiona ou aleija o processo de formulação de políticas públicas e, de fato, ter chegado a pensar que a política pública elaborada de forma inteligente poderia ser bemsucedida onde outras tentativas haviam falhado. De acordo com 
Lindblom, regulações são frequentemente vistas pelo mercado com um desincentivo para investimentos e geração de renda e trabalho. Inúmeras medidas regulatórias são, portanto, imediatamente seguidas pela punição do desemprego. Esse é o motivo pelo qual, para o autor, o mercado pode ser caracterizado como uma prisão. Para uma ampla gama de relações políticas/econômicas, o sistema de mercado aprisiona o processo de formulação de políticas públicas e aprisiona as tentativas de melhorar as instituições sociais. É um mecanismo altamente seletivo que permite certas mudanças, mas impõe obstáculos poderosos para outras. $\mathrm{O}$ autor enfatiza, porém, que o sistema, apesar de aprisionado pelo mercado, não é a prova de fuga, ou seja, não é imutável.

Evitar as dualidades perigosas entre sentimento e racionalidade, Estado e mercado é a proposta de Zelizer (2009), que retoma o argumento neoinstitucionalista de que nenhuma relação de mercado existe sem a infraestrutura de instituições ou sem a presença de compreensões compartilhadas. No entanto, a presença reguladora estatal sobre o mercado depende da sua capacidade de manutenção simultânea de autonomia e inserção (embeddedness autonomy), nos ensina Evans (1986). Na ausência dessa simultaneidade, ou o Estado perde autonomia, tornando-se prisioneiro dos interesses de mercado, ou perde capacidade de inserção, de formular e implementar um projeto de desenvolvimento.

A literatura nos mostra que com a expansão da cidadania foi possível compatibilizar a coexistência de um status igualitário assegurado pelo Estado, em relação a direitos e deveres, em uma sociedade em que as desigualdades de mercado foram parcialmente limitadas pela regulação estatal e pelas políticas distributivas de proteção social (Marshall, 1967). O que interessa é o enriquecimento da vida civilizada, uma redução do risco, da insegurança, uma igualação entre os mais e os menos favorecidos em todos os níveis. Assim, conclui em seu ensaio que "a igualdade de status é mais importante do que a igualdade de renda" (ibidem:95). Em outras palavras, a desigualdade inerente ao sistema de classes é passível de aceitação se a igualdade de cidadania for reconhecida como um "status concedido àqueles que são membros integrais de uma comunidade. Todos aqueles que possuem o status são iguais com respeito aos direitos e obrigações pertinentes ao status" (ibidem:76).

Essa trajetória da construção da modernidade democrática capitalista foi contraditória, dependendo das relações e instituições sociais exis- 
tentes em cada contexto histórico. Será mais ainda em sociedades marcadas pela desigualdade e exclusão social, cuja governabilidade democrática dependerá da capacidade estatal de gerar inclusão ativa da cidadania, rompendo barreiras discriminatórias impostas pelo mercado, pela cultura elitista e pela persistência de modalidades de apropriação de bens públicos por alguns poucos (Fleury, 2004; Calderón, 1995). A busca de um rearranjo destas relações entre Estado, mercado e comunidade é também o desafio da governança necessária à consecução de políticas públicas efetivas em um contexto de marcadas assimetrias.

A expansão da cidadania tende a combinar componentes contraditórios, o que permite diferentes leituras e disputas em relação a este conceito, desde uma perspectiva libertária a outra, de natureza mais igualitária. Nos seus extremos, a liberdade irrestrita, mesmo favorecendo o mercado, gera ameaças à existência da sociedade, enquanto a igualdade, quando implica restrição à livre ação dos indivíduos, compromete o princípio básico no qual o mercado se sustenta. Por outro lado, tanto o mercado requer a igualdade formal para o estabelecimento das trocas contratuais e suas garantias legais, quanto a igualdade jurídica pressupõe a autonomia dos sujeitos para que se efetive. Estas tensões inerentes à construção do Estado moderno e de suas interfaces com o mercado e a cidadania tendem a aprofundar-se com a complexificação das sociedades, nas quais as reivindicações de igualdade e liberdade passam a se somar com as de reconhecimento das diversidades e requisitos de participação cidadã na gestão da coisa pública (Fleury, 2003; Fraser, 2003; Young, 2000).

Para Amartya Sen (2000), a subordinação da igualdade pela liberdade, ou vice-versa, é um falso paradoxo que seria resolvido com sua compatibilização por meio da introdução da noção de capacidade. Só por meio do desenvolvimento de capacidades os indivíduos poderiam exercer plenamente igualdade e liberdade. Assim, enquanto a pobreza é tradicionalmente identificada como um mero baixo nível de renda, para Sen (2000) ela deve ser vista não somente como uma renda baixa, mas, principalmente, como uma situação de privação de capacidades básicas; capacidades por ele entendidas como possibilidades de ser e de fazer do indivíduo, tais como ser saudável, bem nutrido, ter conhecimento, participar da vida da comunidade. A privação relativa de rendas pode resultar em privação absoluta de capacidades. Essa ideia está associada com o custo de vida de uma dada sociedade e das exigências 
contextuais para os indivíduos participarem da vida da comunidade, as quais podem ser severas. Sen aponta a possibilidade de compatibilização entre mercado e sociedade por meio da intervenção governamental, única forma de assegurar oportunidades iguais e respeito à liberdade. O conceito de capacidades, no entanto, não discute a questão da distribuição do poder, tomando-a como reflexo do incremento de capacidades, o que tende a obscurecer a discussão sobre modelos alternativos de políticas que se configuram na tensão das alianças entre governantes e empresários na busca pela expansão do mercado, em detrimento da comunidade dos cidadãos.

\section{EXPANSÃO DO MERCADO LOCAL}

\section{Empresas Sobem o Morro}

De acordo com Burgos (2005), os moradores das favelas, embora de baixa renda, representam um mercado consumidor bastante dinâmico. Assim como indivíduos que moram em outras localidades da cidade, pensam e agem como atores de mercado. Portanto, de olho nos consumidores que ali habitam, o período pós-pacificação é marcado pela entrada de grandes empresas no morro, que direcionam suas atividades para o mercado antes inacessível de forma direta.

Em setembro de 2010 foi inaugurada, na Praça Cantão, principal espaço comercial da comunidade, uma mini Casa \& Vídeo, loja que vende desde eletrodomésticos a pequenos utensílios. O imóvel alugado pela empresa pertence ao empresário local apelidado pela grande imprensa de Eike Batista do Santa Marta.

O banco Bradesco instalou, em meados de 2010, no prédio da creche localizada na rua Jupira, principal rua da favela, um Posto de Atendimento Avançado. Com apenas um funcionário, realiza atividade gerencial relacionada à concessão de crédito e disponibiliza um caixa eletrônico. Há, ainda, o serviço realizado pelo o que chamam de Bradesco Expresso, o qual pratica a atividade operacional de um banco, ou seja, abre contas, recebe pagamentos, depósitos, abre cartões e faz saques. $\mathrm{O}$ Santa Marta possui três comerciantes que operam como Bradesco Expresso, e esses comerciantes locais, parceiros do Bradesco, são pagos por cada transação que realizam e, como ressaltou nosso entrevistado, "recebem bem para isso". A adaptação às condições locais é patente na redução dos requisitos para abertura de contas e tomada de empréstimos. 
A expansão do mercado é, pois, uma realidade vista como positiva por empresários e moradores. No entanto, a inserção da população se dá fundamentalmente como consumidores, já que não há menção à forte expansão do mercado local de trabalho como parte desse processo, a não ser a incorporação de moradores em serviços pouco qualificados e temporários das obras do PAC.

\section{Diversificação}

A grande repercussão da política pública no Santa Marta estimulou o surgimento de um projeto pioneiro, o Rio Top Tour, tornando a comunidade parte do roteiro turístico oficial da cidade. Realizado com o apoio do Ministério do Turismo, da agência de fomento do Governo do Estado e do Serviço Brasileiro de Apoio às Micro e Pequenas Empresas (Sebrae), sendo este último o responsável pela capacitação de moradores como guias turísticos, o projeto tem se mostrado uma nova oportunidade de fonte de renda para os moradores, principalmente como guias. Outros guias locais, entretanto, optaram por seguir como autônomos e não se envolveram com o projeto Rio Top Tour, quer por já desenvolverem outros projetos turísticos anteriormente, ou por considerarem que podem ganhar mais de forma independente. Há, ainda, o turismo realizado por empresas de fora da comunidade, que chegam na favela por meio de jipes. Estes são, com frequência, criticados pelos moradores por não contribuírem com a economia local. A polarização entre empreendedores no ramo do turismo, internos e externos, tem aumentado a cada dia, o que tem levado à organização coletiva dos empreendedores locais em busca da defesa do seu lugar nesse mercado. Enquanto os empreendedores locais baseiam seu negócio no capital cultural que detêm, o desnível em relação aos empreendedores externos que trazem os turistas desde os hotéis com seus meios de transporte, falando inglês e transmitindo maior segurança, favorece enormemente suas atividades.

Comerciantes locais se dividem em relação à opinião sobre os benefícios do turismo para seus negócios. Enquanto muitos alegam que os visitantes não compram nem água mineral por receio de algum tipo de contaminação, outros dizem que começam a se beneficiar com o aumento da frequência, em especial nos bares.

Eventos festivos nos fins de semana, em especial rodas de samba, têm atraído público de fora da comunidade, disposto a gastar somas altas, 
para o padrão local, com a entrada nos eventos, além de comes e bebes. Os eventos mais conhecidos são as rodas de samba e outros shows que ocorrem na Quadra de Samba da Mocidade Unida do Santa Marta, localizada na Praça Cantão. As famosas rodas de samba organizadas pelo grupo do bloco de carnaval da Zona Sul, Spanta Neném, atraem um público classe média que enche a quadra e seus arredores na Praça Cantão, onde estão localizados diversos bares. O bloco de carnaval custeia outras duas bandas que tocam do lado de fora da quadra, com acesso livre a todos. Assim, a circulação de pessoas e o consumo permanecem intensos quando ocorrem tais rodas, deixando os comerciantes dos bares em constante expectativa para o próximo evento. Além disso, a nova clientela altera a dinâmica do comércio em questão ao exigir produtos, frequentemente de preço mais elevado, com os quais não estavam acostumados a trabalhar, como nos relata uma comerciante local:

[...] antigamente, você lidava só com a comunidade; hoje em dia, não, você lida com outro tipo de pessoas [...]. A pessoa ganha confiança de vir pra comunidade, o comércio ganha confiança de atrair a pessoa também pra comunidade. Isso é um ganho muito grande pro comércio; eles ficam contando os dias pro próximo evento. [...] tanto que eu mudei muito o meu jeito de trabalhar. Eu não vendia... não sei, eu não vendia vodka, eu não vendia nada, fui aprendendo com eles. Eu passei a comprar vodka, que eu não comprava, passei a comprar energético, que eu não comprava, passei a comprar whisky, que eu não comprava; uma vodka cara à beça, que uma garrafa, você vai comprar, é $\mathrm{R} \$ 100,00$. Que diabo de vodka é essa?! Mas é assim, você acaba se acostumando com a forma das pessoas, com a aproximação da pessoa, entendeu? É totalmente diferente do pessoal aqui do morro. [...] é muita roda de samba que tem, é muito evento que tem, e é só gente de fora, não é ninguém do morro. Não dizendo que a comunidade não gasta; gasta, mas quando esse pessoal vem, vem com uma disposição de gastar que eu nunca vi na minha vida; não tem dia, nem hora, nem data, entendeu? Todo dia é bom. Pelo menos pra comunidade é no começo do mês; pra eles não, pra eles é no começo, meio e fim, que é bom, entendeu?

A fala da comerciante nos mostra que a maioria dos eventos que ocorre na quadra da escola de samba e na Praça Cantão, que fica em frente à quadra, tem sido para pessoas de fora da comunidade. A mudança na dinâmica dessa área comercial do morro leva os comerciantes a buscarem se adaptar ao gosto da nova clientela ao adquirirem produtos dife- 
renciados. O fato de que a maioria dos eventos na quadra são direcionados às pessoas de fora agrada aqueles comerciantes que lucram mais com o público externo. Ademais, a sensação de segurança que a presença permanente da polícia gera, desperta a confiança para que pessoas do asfalto frequentem o morro e, consequentemente, possibilita ao comerciante investir por acreditar que tal movimento da freguesia se sustentará.

Assim, por um lado, há aqueles que foram beneficiados pelo aumento da circulação de turistas e de pessoas com maior poder aquisitivo, como os bares e restaurantes localizados em pontos que fazem parte do trajeto turístico e, principalmente, os empreendimentos localizados na Praça Cantão, como os citados anteriormente. O dono de um bar no meio do morro relata a expansão do empreendimento proporcionada pela retirada do domínio armado do tráfico. Antigo ponto de olheiros do tráfico, a chegada da UPP promoveu uma grande mudança para o bar.

Por outro lado, existem aqueles comerciantes que se sentem prejudicados pela maior inserção do Estado, em especial aqueles que não se enquadram no comércio voltado aos turistas ou ao público externo. $\mathrm{O}$ aumento dos custos pela regularização dos serviços de luz e água, bem como a imposição da formalização dos empreendimentos torna o comércio mais custoso. Ademais, o fato de os moradores terem que arcar com a formalização dos serviços supracitados e da TV a cabo compromete boa parte do orçamento, resultando numa disponibilidade financeira menor para consumir no interior da comunidade.

Por fim, o comércio a mbulante localizado na entrada do morro se sente inseguro com a entrada do Estado e sua ordem. A Associação Comercial do Santa Marta, juntamente com os próprios ambulantes, lutam pela sua permanência por meio da legalização das barraquinhas por parte da Prefeitura, ainda sem uma efetiva resposta do ente.

Em resumo, a diversificação das atividades do comércio local favorece aqueles empreendedores e negócios que se inserem na nova dinâmica de relação com a favela, em especial nos ramos do turismo e do comércio de bares e festas voltados para o público externo. Além da competição entre os negócios locais e externos no mesmo ramo, que favorece grandemente os agentes externos, a dinâmica do mercado direciona as atividades para o público externo, reestratificando o mercado em detrimento daqueles comerciantes que têm como consumidores a popu- 
lação local, cujo poder aquisitivo vem sendo reduzido com a formalização das relações de consumo.

\section{Formalização}

Com a maior inserção do Estado nas favelas cariocas, viabilizado pela implantação de UPPs, teve início o processo de regularização de consumo de serviços e de atividades comerciais. De acordo com dados do Sebrae $^{7}$, cerca de 92\% dos negócios nas favelas cariocas são informais. O projeto Empresa Bacana, organizado pela Diretoria de Desenvolvimento Econômico do Instituto Pereira Passos e realizado pela Prefeitura em parceria com o Sebrae e o Sindicato de Empresas de Serviços Contábeis (Sescon), oferece aos que faturam até R \$ 36 mil por ano a chance de formalizar o seu negócio pagando mensalidades que variam de $R \$ 28,25$ a $R \$ 32,25$. O mutirão tem sido realizado em cada comunidade pacificada, as quais são o foco atual do projeto.

Segundo relatos de alguns entrevistados, o maior atrativo aos olhos do microempreendedor na favela Santa Marta é a possibilidade de, com o número do CNPJ (Cadastro Nacional de Pessoa Jurídica) em mãos, adquirir o sistema de vendas por cartão de crédito, o que representa mais possibilidades de vendas para os comerciantes que se beneficiam com a mudança de clientela. De acordo com a Associação Comercial do Santa Marta, hoje são 70 comerciantes formalizados na comunidade.

Um segundo aspecto relevante da formalização é o da regularização dos serviços no Santa Marta após a instalação da UPP. Em substituição aos chamados "gatos", prática até então comum de acesso irregular à luz e TV a cabo, regularizou-se o fornecimento destes serviços, bem como o de água.

O fornecimento de energia elétrica foi o primeiro serviço a ser regularizado após a implantação da UPP (Cunha e Mello, 2011). Segundo dados da concessionária Light, 90\% dos domicílios não possuía fornecimento legal de energia. Hoje, o número de famílias com o fornecimento regularizado saltou de 73, antes da UPP, para 1.594. Essas alterações refletiram, outrossim, nos rendimentos da empresa. Segundo reportagem veiculada pelo jornal O Globo, em 3 de janeiro de 2012, o valor cobrado pela empresa no Santa Marta aumentou em $5.437 \%$, passando de $\mathrm{R}$ \$ 1.585,64 antes da ocupação, para $\mathrm{R} \$ 87.799,04$, em dezembro de 2011. Por sua vez, a arrecadação no referido mês ficou em $R \$ 79.509,12$, contra apenas R\$242,17 do período anterior à UPP, pois, dos 73 consu- 
midores com fornecimento regularizado, somente $15 \%$ pagava. Ademais, a arrecadação de ICMS (Imposto sobre Circulação de Mercadorias e Serviços) também disparou, passando de $\mathrm{R} \$ 285,42$ do mês anterior ao projeto ser implantado, para R \$17.854,80 em dezembro de 2011. O aumento da arrecadação do imposto estadual, dessa e de outras fontes, é visto por alguns como uma compensação bem-vinda para as contas do Estado do Rio de Janeiro diante do aumento dos custos com as UPPs.

Buscando maior envolvimento dos moradores no programa de eficiência energética e a redução do impacto da cobrança regular da energia consumida, a Light realizou a troca de antigas geladeiras por novos modelos, mais econômicos, fez reformas elétricas em casas, trocou lâmpadas e realizou ações educativas. Tais ações são reflexos de determinações da Agência Nacional de Energia Elétrica (Aneel), que estabelece que empresas concessionárias ou permissionárias de distribuição de energia elétrica devem aplicar um percentual mínimo da receita operacional líquida (ROL) em programas de eficiência energética voltados a comunidades de baixo poder aquisitivo (Aneel, 2008).

Um sistema de telemedição permite que a concessionária realize um controle remoto que a possibilita fazer cortes e ligações diretamente da empresa, sem precisar ir ao local, como fazia anteriormente. Além disso, a Light instalou iluminação pública em diversos becos e vielas da favela, bem como afixou placas com os respectivos nomes e numerações nas edificações, de modo a garantir a entrega da conta de luz diretamente em cada residência, passando os moradores a ter um endereço (Cunha e Mello, 2011). Até o presente momento, essa é a única correspondência entregue nas casas, o que é feito pela própria Light. A conta de luz é também um comprovante de residência, importante para a condição de cidadania do indivíduo, e que antes era emitido pela própria associação de moradores.

Durante o período de transição foi fixado um teto de cobrança do consumo, medido em quilowatts-hora, estabelecido a partir da média do consumo local. Esse teto, revisado e ampliado a cada quatro meses, tinha como objetivo "adaptar" os moradores à nova cobrança, pois, quando retirado o teto estipulado ${ }^{8}$, a tarifa cobrada seria a mesma do asfalto. O desconto é previsto somente para aqueles que possuem Número de Inscrição Social (NIS) por estarem vinculados a programas sociais como o Bolsa Família ou o Cheque Cidadão, ou para aqueles que 
participam do projeto Light Recicla, que, implantado primeiramente no Santa Marta, prevê a troca de lixo reciclável por desconto na conta de luz.

De acordo com o representante da Light entrevistado por nós, a empresa tem a intenção de tratar o morador de favela como um cliente normal. Ele coloca a questão do próprio dilema da compatibilização entre o mecanismo de mercado e a condição de cidadania de como tratar igualmente pessoas tão desiguais: "a gente não quer criar uma 'Lightinha' separada [...] eu quero tratar esse cliente como cliente da Light, não como coitadinho".

A nova cobrança, mesmo no período em que se encontrava reduzida pelo teto estipulado, tem impactado consideravelmente o orçamento dos moradores e é alvo frequente de reclamações. A queixa esteve presente em todas as entrevistas que realizamos e podemos classificá-las como sendo fundamentalmente de três naturezas: arbitrariedade associada à falta de transparência na medição do consumo; desconfiança da atuação da companhia gerada pela falta de transparência; e insegurança financeira que a cobrança considerada abusiva provoca, como expressa a fala de um dos entrevistados transcrita a seguir:

Aumentou muito. Estou pagando R \$2,00 de luz. Eu acho assim, que é um absurdo. A gente não tem um relógio próprio pra poder a gente estar medindo a nossa luz; esse relógio é fechado numas caixas ali embaixo, então, eles vêm aleatoriamente e colocam. E deu pra ver que está sendo abusivo porque teve uma época que a gente ficou sem chuveiro elétrico e sem máquina de lavar, então, esquentava a água pra tomar banho, e eu descia pra lavar a roupa na minha mãe; a luz continuou vindo no mesmo valor. Quer dizer, máquina de lavar e chuveiro, que são coisas que puxam muito, sem funcionar, e ainda assim vem esse valor todo, então assim, você percebe que é abusivo.

Dado que a energia elétrica é um serviço considerado imprescindível, o não pagamento e o consequente corte do fornecimento é evitado com empenho pelos moradores. De fato, o percentual anual de adimplência no Santa Marta chega a 97\%, superior aos $94,34 \%$ registrados na rede de baixa tensão (residências e pequeno comércio) da empresa em toda a sua área de concessão. Entretanto, a conta de energia não diferenciada para os moradores de favela é um dos grandes fatores de empobrecimento na comunidade. 
O fornecimento de água também tem sido alvo de polêmica. Moradores receiam que a conta de água apresente o mesmo aumento gradual que a cobrança da energia elétrica. Segundo relato de moradores, a cobrança iniciou-se com uma taxa considerada baixa por eles, $\mathrm{R} \$ 8,00$. Entretanto, com o tempo, passou para $\mathrm{R} \$ 18,00$, pois agora inclui a taxa de esgoto no valor de R\$10,00. Esta é outra reclamação unânime entre os moradores, que argumentam ser descabida a cobrança por um serviço que não é prestado, visto que não possuem saneamento adequado, com valas abertas e a sujeira que as acompanha espalhadas pela comunidade, além da irregularidade no fornecimento de água.

Uma moradora expressa, no trecho a seguir, seu descontentamento com a precariedade do serviço prestado pela Companhia Estadual de Águas e Esgotos (Cedae) e atribui a má qualidade do serviço à discriminação associada ao morador de favela. Apesar de estar sendo cobrada, não se sente tratada como igual, ferindo sua condição de cidadania.

Então, estamos pagando água agora, taxa de água, R\$ 18,00. Eu acho que todo mundo tem que pagar pelo que usa. Estamos uns 20 dias sem água. Tem uns 20 dias que a gente está assim: eles fecham a água, porque eles têm que consertar, mas eles não deram prioridade pra vir consertar porque o governo tem que entregar uma [outra] obra, então a equipe da Cedae está lá pra poder fechar esse local; e aí a gente fica... Porque é favelado. [...] Só água, não, estamos pagando água e esgoto -é pior, né, não existe o esgoto!

Outro serviço que foi formalizado e que impactou no orçamento do morador do Santa Marta foi o de TV por assinatura. Moradores relatam que este é mais um custo com o qual não estavam habituados e que afeta as finanças. Assim que a empresa Sky formalizou o fornecimento do sinal da TV por assinatura, logo após a chegada da UPP, os pacotes oferecidos eram os mesmos do asfalto. Muitos moradores aderiram, fazendo dessa despesa mais um fator de empobrecimento. Relatam que tentam cancelar o serviço, mas existe um contrato que prevê alta multa em caso de rescisão contratual.

Após experiências como a do Santa Marta e de outras favelas pacificadas mostrarem que a cobrança do valor praticado no asfalto para aquela nova clientela traria problemas, a empresa Sky e o governo do Estado do Rio de Janeiro chegaram a anunciar, em setembro de 2010, um termo de cooperação e um pacote desenvolvido pela operadora especialmente para as áreas pacificadas, o SKY UPP (Terra, 2010), que seria 
oferecido por uma mensalidade mais baixa, no valor de $\mathrm{R} \$ 44,90$. Contudo, os moradores do Santa Marta com os quais conversamos relataram desconhecer o pacote de menor preço.

Comunidades pacificadas têm se mostrado um atraente mercado para as empresas de TV por assinatura. A forma abrupta e incisiva como esse novo mercado consumidor foi abordado no início do processo de formalização gerou estranheza e incômodo. Hoje, "a Sky já vem dentro do caminhão do Bope" é uma piada ouvida com frequência nas favelas de modo geral (Banco Mundial, 2013). A reclamação mostra o desapontamento dos moradores em relação a um tipo de presença do Estado que de fato regulasse o mercado, protegesse os cidadãos contra abusos e ampliasse a gama de serviços que atendessem as suas necessidades, como saúde, educação e saneamento. Não se trata da ausência do mercado, ou do Estado, mas das relações entre eles e seus impactos sobre a comunidade.

As tensões entre diferentes lógicas concernentes à ação do Estado, do Mercado e da Comunidade foi apontada por Offe (1998), para quem há uma incoerência básica entre os princípios que regem a ação coletiva em cada uma destas esferas - respectivamente a razão, o interesse e a (com)paixão -, o que gera contradições. A sinergia e o virtuosismo da relação entre princípios de natureza tão díspar não é facilmente encontrada, como constata Lechner (2000) ao estudar os resultados do paradoxal crescimento econômico chileno nas últimas décadas. O desenvolvimento econômico sob a égide dos interesses do mercado, com uma grande retração das garantias sociais do estado de bem-estar, gerou uma sensação de mal-estar difuso, uma crescente insegurança entre os cidadãos acerca de como será seu futuro sem garantias legais de direitos asseguradas pelo Estado.

No caso estudado na pacificação da favela, o predomínio da lógica do mercado, fortemente amparado pela política pública de segurança, gera na população um sentimento ambíguo de orgulho de poder assumir um lugar formalizado, ao lado de uma grande insegurança em relação às consequências desse processo sobre a vida de cada indivíduo e da comunidade como um todo.

\section{RESPONSABILIDADE SOCIAL E CAPACITAÇÃO}

Além da expansão das atividades típicas do mercado, encontramos um conjunto de ações desenvolvidas por agentes de mercado, apoia- 
das pelo governo e em apoio às políticas públicas, voltadas para a promoção social junto aos moradores da favela. Elas podem ser englobadas na categoria de responsabilidade social empresarial, estando voltadas para o desenvolvimento da imagem da empresa junto a esse público e ao aumento das capacidades dos moradores.

Encontramos ações de diferentes naturezas em termos de responsabilidade social (Rodrigues, 2004) na favela Santa Marta. Elas visam construir uma boa imagem da empresa ou instituição perante a comunidade e a cidade, mas ao mesmo tempo possuem outras especificidades.

A primeira está vinculada ao sistema corporativo, que tem uma relação próxima com o Estado e intensa atuação na comunidade. Fruto de um acordo firmado entre o governo do estado e da prefeitura do Rio de Janeiro com o sistema Firjan (Federação das Indústrias do Estado do Rio de Janeiro), o programa SESI (Serviço Social da Indústria) Cidadania é realizado especificamente nas comunidades pacificadas do Rio de Janeiro. Lançado em agosto de 2010, o programa leva serviços gratuitos de educação, cultura, saúde, esporte e lazer a moradores de 19 regiões com UPPs.

O programa Indústria do Conhecimento, vinculado ao SESI Cidadania, e cujo objetivo é a promoção do acesso à informação e ao conhecimento, teve sua quinta unidade implantada no Santa Marta, em setembro de 2011. Segundo alguns moradores, o fato de tal espaço ter sido instalado no Polo de Inclusão Social Padre Veloso, unidade do poder público onde estão situadas outras instâncias de ação social, localizado na Praça Corumbá, na entrada do morro pela rua São Clemente, trouxe uma nova dinâmica para o Polo, o qual estava subaproveitado. Para nós, o fato de o programa da Firjan no Santa Marta se situar nesse local deixa clara a articulação existente entre a Federação e o Estado.

A segunda diz respeito à responsabilidade social imposta por regulação estatal. Como foi dito no tópico acerca da formalização, as ações de eficiência energética da concessionária Light direcionadas às comunidades de baixo poder aquisitivo estão associadas à determinação da Aneel. A literatura não é unânime e aponta que essa forma de atuação pode ou não ser vista como ação de responsabilidade social empresarial, visto que não é voluntária. Contudo, essa regulação evidencia a importância da ingerência estatal na compatibilização entre mercado e cidadania. 
A terceira se refere às atuações esporádicas que visam manter relações com a comunidade e estão, em geral, vinculadas ao objetivo de aumentar a venda de produtos ou atrair mão de obra. Uma delas foi a abertura de vagas para contratação de moradores de comunidades pacificadas para a função de atendente de call center na empresa responsável por esse serviço na Light. Já o banco Bradesco e a Casa \& Vídeo buscam apoiar atividades organizadas pela comunidade, como a festa do Dia das Crianças, além de oferecer vagas de emprego em suas lojas.

Por outro lado, a maior presença do Estado na favela também está associada ao empenho de diversos setores em desenvolver ações socais visando ao aumento de oportunidades e capacidades. O indubitável aumento de ofertas de cursos e atividades é contrastado com a situação anterior, cujo único mercado era o do tráfico, mas criticado por outros por sua descontinuidade, ineficácia e inadequação às necessidades.

Segundo o comandante da UPP Santa Marta, capitão Andrada, antes as pessoas tinham que conviver com o tráfico, hoje a UPP lhes dá escolha. De acordo com o agente comunitário do programa SESI Cidadania e morador do Santa Marta, as oportunidades aumentaram e muita coisa está chegando: "Onde tem segurança melhora tudo. Oportunidades estão batendo na porta, só não faz quem não quer". O período pós-UPP permitiu que novas oportunidades chegassem à comunidade, segundo alguns dos entrevistados. Enfatizam o aumento da oferta de trabalho, de projetos e serviços públicos, de cursos profissionalizantes e oportunidades de trabalho.

Porque hoje é assim, aqui tem vários projetos, tem projeto do estado, do
município, tem um polo da saúde; então assim, melhorou por isso, por-
que, se não houvesse a UPP, isso não viria pra comunidade, não teria o
polo aqui, na praça, não teríamos a Faetec ${ }^{9}$ aqui do lado; não teríamos
várias coisas aqui dentro, os eventos da quadra...

Por outro lado, um morador relata que os cursos que têm chegado ajudam muito, sim, mas enfatiza que o estigma de favelado os acompanha, e, para terem capacidade e poderem participar da vida da cidade ainda devem se destacar.

Finalmente, há também moradores que acreditam que os cursos oferecidos por instituições como Faetec e Senai (Serviço Nacional de Aprendizagem Industrial) não condizem com os anseios da população e principalmente dos jovens. Para eles, tais cursos não dão oportunida- 
des e capacidades novas para os jovens, mas os limitam aos subempregos que o mercado lhes oferece e nos quais prefere mantê-los.

A pobreza, para Sen (2000), deveria ser vista não apenas pelo baixo nível de renda, mas principalmente como uma situação de privação de capacidades básicas. A privação relativa das rendas pode resultar em privação absoluta de capacidades. No entanto, essa noção de capacidades está associada com o custo de vida de uma dada sociedade e com as exigências contextuais para os indivíduos participarem da vida da comunidade. Essas exigências não são apenas materiais, podendo ser exclusões decorrentes de estigmas e outros critérios simbólicos. Assim, o investimento em atividades de capacitação deve levar em conta as exigências contextuais, materiais e simbólicas, se pretende contribuir para a redução das desigualdades. A inadequação entre a oferta e as expectativas, bem como a ineficácia de muitas das ações, como apontadas pelos moradores, em especial os jovens que deveriam ser o público-alvo, mostra uma baixa capacidade de planejamento e execução dessas políticas, nas quais estão envolvidos governantes e representantes empresariais.

\section{EFEITOS NA SOCIABILIDADE}

A nova dinâmica instaurada na favela a partir da pacificação e do processo imediato de expansão do mercado em suas diversas formas tem gerado efeitos desestabilizadores da sociabilidade existente, mostrando que a inclusão pelo mercado produz, paradoxalmente, novas formas de estratificação e exclusão que se evidenciam na privatização dos espaços públicos e nas inseguranças em relação a uma remoção branca que estaria em curso.

\section{Mercantilização dos Espaços Sociais}

Com a sensação de segurança trazida pela política de segurança pública, a favela se mostrou um local lucrativo ao atrair pessoas de fora da comunidade que buscam nos eventos que ali ocorrem algo diferente, em especial aqueles que são realizados na quadra da escola de samba. Dessa forma, os moradores, que tinham como principal espaço para festas a quadra da escola de samba, sentem que perderam espaço em sua própria comunidade para aqueles de fora que agora aproveitam para lá circularem e para os que lucram com a mudança de público,

DADOS - Revista de Ciências Sociais, Rio de Janeiro, vol. 56, nº 3, 2013 
além de sofrerem com a ordem imposta pela UPP para a realização de suas festas.

As festas para pessoas de fora da comunidade não ficam restritas à quadra da escola de samba. Uma vez por mês a Laje do Michael Jackson $^{10}$, outro espaço de socialização dos moradores, é ocupada por uma roda de samba organizada por um morador juntamente com outros três músicos do asfalto, que, apesar de ser gratuita e aberta a todos, tem como principais frequentadores os cariocas de fora da comunidade e turistas estrangeiros buscando lazer alternativo.

Além da perda do espaço para suas próprias festas e eventos de lazer, a intensa movimentação de pessoas motivadas pelas festas ou pelo turismo praticado na favela incomoda os moradores que têm a circulação prejudicada pelo congestionamento de pessoas nas estreitas vielas. Alguns moradores se sentem incomodados com a presença de indivíduos com os quais não se identificam circulando pela comunidade e olhando dentro de suas casas. Muitos se queixam do barulho e da sujeira deixada pelos visitantes nas proximidades dos locais das festas. $\mathrm{Ou}-$ tros questionam por que a infraestrutura da comunidade não é beneficiada com a entrada dessa nova renda, e, sim, apenas aqueles que lucram diretamente com os eventos.

Para alguns moradores, o turista é inconveniente quando não respeita a privacidade daqueles que ali habitam. Descrevem situações em que o visitante fotografa pessoas em momentos privados sem pedir autorização:

Porque verão, calor, a gente dentro de casa, né, você está de short, você está de top, e já vêm pessoas fotografando assim, dentro de casa: "Ah, que interessante!", como se você fosse assim, um ser esquisito, sabe, não pergunta [...] a pessoa fotografa sem perguntar, sem pedir autorização? Não é assim. Então, houve muito também uma invasão, sabe?

Assim, apesar de alguns defenderem que esse movimento de subida do morro por pessoas de fora dele é uma oportunidade de integração morro/asfalto e possibilita a desmistificação do estereótipo do favelado devido à percepção mais próxima daquela realidade por aqueles que não a conheciam, o que predomina é o sentimento de perda de espaço para a exploração mercadológica. Ademais, pouco conseguem interagir com a cidade, que também costuma praticar preços elevados, ou seja, agora ambos fora do alcance do favelado. A integração não 
ocorre se não acontecer nos dois sentidos: asfalto-morro, morro-asfalto. Portanto, o que tem ocorrido na comunidade Santa Marta é mais uma invasão da classe média e uma mercantilização dos seus espaços sociais, ou seja, um movimento de expansão do mercado com restrições para os moradores locais. A ausência de uma entidade do governo que resguardasse os espaços públicos da exploração exclusivamente lucrativa, o que representaria o duplo movimento requerido para proteção da cidadania, mostra a capacidade destrutiva do mercado em relação à sociabilidade, apontada por Polanyi (1980).

\section{Inseguranças}

A nova realidade vivida pela favela Santa Marta após a implantação da política pública da UPP e maior inserção do Estado tem trazido diferentes benefícios para aquele território. Por outro lado, são várias as inseguranças causadas pelas recentes mudanças. A primeira que apontamos aqui diz respeito à própria política pública das UPPs. Os moradores de favelas já assistiram a algumas iniciativas de policiamento comunitário darem errado, o que gera grande desconfiança e insegurança. Itamar Silva, membro do Grupo ECO, comenta a experiência vivida com o Destacamento de Polícia Ostensivo (DPO) no governo Anthony Garotinho: oito meses depois da instalação, a DPO se retirou do morro e, em seguida, aconteceu uma das piores guerras entre quadrilhas (Pandolfi e Grynszpan, 2003:331).

Este exemplo nos permite entender o sentimento atual da comunidade diante da política pública das UPPs. O receio de que a iniciativa se deva puramente aos interesses associados aos megaeventos que serão sediados pela cidade - alguns jogos da Copa do Mundo de 2014 e as Olimpíadas de 2016 - desperta grande desconfiança nos moradores, além da percepção de que predomina o "interesse deles", o qual não coincide com o "nosso", como na fala seguinte:

A obra está vindo, essas coisas estão vindo e todo mundo sabe que é por causa da Olimpíada. Ninguém tira isso da minha cabeça, nem da cabeça das pessoas que têm um pouquinho mais de conhecimento. Não está vindo porque eles gostam do Santa Marta não, nem da Rocinha, nem do Vidigal, nem Tabajara, nem do morro dos Cabritos. Eles vêm por causa da Olimpíada, é interesse dos governantes, tanto federal, municipal, estadual. Não é porque eles gostam da gente, não é porque eles querem dar o melhor para a gente não. É interesse deles. 
Existe ainda a visão de que o Estado não dá segurança para aquela população; diante disso, alguns optam por se resguardar nesse período de mudanças, que para muitos tem o prazo de validade limitado a 2016. Assim, evitam expor opiniões de forma explícita. A insegurança gerada por essa possibilidade leva um dos entrevistados a considerar sair do morro devido ao medo de ser repreendido pelo progresso alcançado fora do crime, caso os traficantes voltem a dominar o território:

Se a UPP sair... Cara, eu vou ser sincero a você, eu acho que eu saio do Santa Marta. Porque vai acontecer uma série de situações, provavelmente guerras, que vão afetar muitas pessoas, e eu vou ser um desses afetados. Ninguém quer ver você bem, ninguém quer ver você ganhando num trabalho com dignidade; se você está bem, você é mau; eles [se referindo aos bandidos] querem ver você no buraco, afundado lá, no fundo do poço. [...] Eu vou ser bem sincero, o BOPE ficou aqui durante 10 meses; quando o BOPE saiu, foi uma das guerras mais sangrentas do Santa Marta.

Segundo Itamar Silva (Grupo ECO), "quando a polícia se instala, para impedir [...] atritos, há uma certa paz. Mas quando ela sai - pode ficar até um, dois anos -, há uma cobrança em cima daqueles que, de alguma forma, se protegeram com a intervenção da polícia" (Pandolfi e Grynszpan, 2003:342).

Aqueles que residem no pico do morro, local com moradias mais humildes e com menor infraestrutura, enfrentam outra insegurança: a possibilidade de remoção. A Prefeitura argumenta que o motivo para a remoção se deve à situação de risco em que se encontram as casas ali localizadas. Contudo, alguns moradores entrevistados atribuem a possível remoção ao interesse da Prefeitura e de empresários em criar um grande ponto turístico no pico do morro. Seja essa crença verídica ou não, o fato é que aqueles moradores se encontram constantemente sob o medo da remoção de suas casas e questionam por que a verba disponível para reassentá-los ou indenizá-los não é utilizada para dar-lhes a segurança que as autoridades argumentam faltar.

A literatura de política urbana (Carrión, 2007) chama a atenção para a penetração do grande capital nacional e internacional na disputa pelo espaço urbano, o que produz transformações nos marcos institucionais e nas modalidades de gestão pública, com a privatização da cidade e a concentração de capitais. A esse projeto de cidade empresarial 
privada no qual a urbe é normatizada a partir da perspectiva mercantil, se oporia uma visão crítica da gestão pública, que propõe um modelo de gestão participativa. Entretanto, no lugar do planejamento moderno, fortemente marcado por uma ação diretiva do Estado, predomina um planejamento competitivo, que se pretende flexível, amigável ao mercado (market friendly), orientado pelo e para o mercado (market oriented), que possui como ideário a "cidade-empresa" (Vainer, 2011). Neste modelo ocorre um deslocamento do processo decisório desde os conselhos participativos para as corporações em relação estreita com os governantes.

A remoção dos moradores do pico demonstra bem esse processo decisório cerrado, o que gera enormes desconfianças por parte dos moradores e resistências em aceitar os argumentos apresentados pela Prefeitura. Organizados em defesa da sua permanência, utilizando recursos técnicos como contralaudos sobre riscos de desabamento e também recursos políticos, como mobilização de vereadores e exigência de que sejam ouvidos pelos dirigentes da Prefeitura, os moradores denunciam tanto o modelo decisório quanto a vinculação dessas medidas aos interesses empresariais.

Outra insegurança que apontaremos aqui está diretamente associada ao custo de vida no morro após a maior inserção do Estado. Conforme destacado na categoria formalização, o aumento dos custos associado à regularização dos serviços de energia elétrica, água e TV por assinatura sobrecarrega o orçamento do morador da favela. Além disso, alguns moradores do Santa Marta apontam que os preços praticados pelas biroscas e pequenos comércios, como bar, padaria e restaurante também tiveram os preços inflacionados pelos novos custos com os quais devem arcar e pela procura de uma clientela com maior poder aquisitivo que tem frequentado a comunidade.

Os preços aumentaram muito, porque como agora eles vão ter que pagar taxas também, agora eles pagam luz e os outros impostos que se tem, tudo está muito mais caro. A comunidade está assim, fora da realidade. Não se vende mais pra pessoas que ganham um salário limitado; as coisas estão bem altas. Estão voltados mais pro pessoal de fora. Com certeza. Com certeza! Antigamente, você descia, pedia uma pizza aí família, $\mathrm{R} \$ 10,00$; hoje em dia, é $\mathrm{R} \$ 25,00$. O refrigerante, que antigamente você comprava por $R \$ 3,00, R$ \$, 50, hoje em dia é $R$ \$ 6,00. O açaí, que você comprava por $R \$ 1,00$, hoje em dia é $R \$ 2,50$. Então assim, foi muito... O pãozinho, que era $\mathrm{R} \$ 0,10$, hoje em dia é $\mathrm{R} \$ 0,25$. Uma caixa de lei- 
te, você vai comprar na padaria, é $\mathrm{R} \$ 5,00$. Porque o rapaz da pizza continua trabalhando sem os padrões que a Vigilância Sanitária exige, mas ele aumentou porque ele está pagando luz, aumentou porque o turista está subindo, aumentou porque está tendo vários eventos no Cantão, e assim, ele... Está sendo abusivo; está sendo muito abusivo.

O aumento do preço dos aluguéis também traz insegurança para aqueles que não possuem casa própria. Na parte alta da comunidade houve uma valorização de $200 \%$, enquanto na parte baixa a valorização foi de $74 \%$, como mostra a tabela a seguir.

Valor do Aluguel na Comunidade Santa Marta

\begin{tabular}{l|c|c|c|c|c|c}
\hline & \multicolumn{3}{|c|}{ Parte Alta } & \multicolumn{3}{c}{ Parte Baixa } \\
\hline & Antes da & Depois da & Valoriza- & Antes da & Depois da & Valoriza- \\
& UPP (R\$) & UPP (R\$) & ção em \% & UPP (R\$) & UPP (R\$) & ção em \% \\
\hline Quarto e sala & 150,00 & 450,00 & 200 & 230,00 & 400,00 & 74 \\
Dois quartos & 430,00 & 570,00 & 32 & - & - & - \\
Loja comercial & - & - & - & - & - & - \\
\hline
\end{tabular}

Fonte: Secretaria de Estado de Governo com base nas informações repassadas pelas associações de moradores apud IETS, 2010.

Os trechos seguintes expressam a preocupação de alguns moradores entrevistados no que tange ao aumento da demanda e consequente valorização das moradias:

[...] a gente não está encontrando casa porque você não encontra casa pra alugar no Santa Marta, e, quando você encontra, é $R$ \$ 600,00, $\mathrm{R} \$ 500,00, \mathrm{R} \$ 550,00$, e está muito fora da nossa realidade [...].

Por exemplo, hoje em dia quem tem as suas casas, não querem mais alugar pra moradores do Santa Marta, ou pra uma família que vem do Nordeste, e que precisa trabalhar aqui; eles querem alugar como se fosse um albergue, que é pra turista, temporada. Assim, mudou muito. Foi uma das coisas que mudaram. Tudo está voltado assim: "Vou vender pros turistas. Eu vou ganhar através dos turistas".

A insegurança maior que tanto preocupa os moradores é o risco de uma remoção camuflada, que vem sendo chamada de "remoção bran-

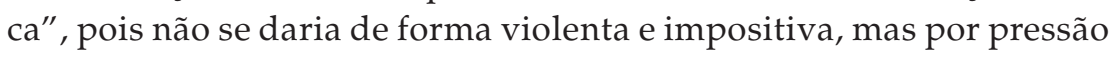
do mercado. Uma comunidade como o Santa Marta, bem localizada na Zona Sul da cidade, com o plano inclinado que favorece o acesso às partes altas do morro, apesar dos constantes problemas, sem tráfico ar- 
mado, pode facilmente atrair o interesse de especuladores (Mattar, Chequer e Dias, 2010). Assim, o aumento dos custos dentro da favela-modelo é fator de pressão para a saída dos atuais moradores.

Outros entrevistados demonstram inquietude e insegurança ao falar da atuação do Estado e do mercado na comunidade. Para alguns, a favela está sendo oprimida e até expulsa pelas ações do governo, que atuaria somente para construir conjuntos habitacionais distantes da área central, ou seja, o processo de gentrificação. Acreditam que o Santa Marta está sofrendo uma grande exploração econômica, o que agrava a sensação de rivalidade entre morro e asfalto, com este sendo percebido como oportunista ao querer aproveitar economicamente a situação de tranquilidade na favela e ao mesmo tempo desrespeitando aqueles que ali habitam.

Eles estão com essa preocupação de tirar a bandidagem, né, o tráfico armado, por conta das Olimpíadas e tal, pra estar vindo pra cá com uma espécie de segurança, mas eles estão oprimindo as pessoas dentro da comunidade, porque tem muitas pessoas aqui que estão... Eu acredito que o governo está trabalhando de maneira assim, a expulsá-los, convidá-los a se retirar daqui, porque a gente está com a conta de luz... a gente já é rua; rua, casa paga IPTU e vários outros atributos, tem várias taxas: taxa de incêndio, taxa de limpeza. Quem vem morar na comunidade, veio fugindo desses impostos, veio correndo, se escondendo desses impostos por não ganhar o suficiente pra poder pagar. Se você for botar na ponta do lápis todos esses encargos, quanto que não vai dar? E aí a empregada doméstica, a patroa dela vai aumentar o salário dela porque agora ela paga luz, porque agora ela paga água, porque agora ela vai pagar taxa de iluminação, vai pagar? Não vai, não vai mudar. Então, vai chegar num ponto que essas pessoas não vão conseguir se manter aqui, e vão sair; o governo vai construir conjuntos habitacionais lá, em Saracuruna, lá, em Seropédica, lá, não sei onde, e vai convidar essas pessoas a irem pra lá, porque elas não vão ter condições de se manter dentro da Zona Sul. Um aluguel aqui está R\$ 600,00.

O termo gentrificação tem sido usado correntemente pelas lideranças nas reuniões das favelas do Rio. Um reflexo do ideário cidade-empresa, apesar de não estar restrito a ele, é o processo de gentrificação ${ }^{11}$, ou enobrecimento urbano. $\mathrm{O}$ termo faz referência ao processo de conversão de áreas habitadas por uma população de menor poder aquisitivo para uma vizinhança com poder aquisitivo maior (Smith, 1979) por meio de uma estratégia do mercado imobiliário normalmente associa- 
do a uma política pública de revitalização dessas áreas degradadas, visando a torná-las mais atraentes ao grande capital.

Segundo Smith (2002), o processo de gentrificação, que inicialmente era esporádico e local, é agora profundamente generalizado em âmbito global. O Estado de tendência neoliberal se torna muito mais um agente do mercado do que um regulador deste, deixando de atuar no sentido da reprodução social e priorizando o capital produtivo. Nesse contexto, a gentrificação pode agravar os já existentes problemas sociais quando a legislação não protege os moradores das áreas afetadas.

A cidade comemora a retirada do domínio armado do tráfico na favela, possibilitando a inserção mais efetiva do Estado e da ordem. Contudo, ignoram-se os problemas causados aos moradores da favela pela exploração econômica que acompanha a nova ordem, como as inseguranças e o medo da remoção branca. Ao contrário, tal exploração é socialmente aceitável e até estimulada ao ser percebida como um processo natural.

\section{CONSIDERAÇÕES FINAIS}

A política pública das UPP no Rio de Janeiro tem sido vista como a possibilidade de devolver à cidade a sensação de segurança de que ela carece. Para além dos efeitos pretendidos, de resgatar os territórios do domínio do tráfico, devolvendo ao Estado o monopólio da coerção, a política de pacificação tem propiciado uma rearticulação entre Estado, mercado e comunidade que merece ser analisada. Este foi o propósito do estudo de caso realizado na favela Santa Marta, tomando como foco a percepção dos agentes envolvidos, tanto do mercado quanto da comunidade. A necessidade de estudar o fenômeno se mostrou evidente, uma vez que há, de fato, uma nova dinâmica de relações entre agentes políticos, econômicos e sociais, que está sendo desenhada de tal forma que esta nova cartografia indica um direcionamento induzido pela política pública que transcende os objetivos e metas anunciados. Tal aspecto é de fundamental importância ao se avaliar os efeitos da política pública em questão, tendo em conta a assimetria de poder e recursos entre os três agentes envolvidos.

A ocupação policial da favela Santa Marta, antes controlada pelo tráfico, e a maior inserção do Estado significou um importante tônico para os negócios de algumas empresas, bem como para o aumento na arrecadação de impostos. Ao mesmo tempo em que os moradores apreci- 
am a facilidade de acesso a certos produtos e a melhoria na prestação dos serviços de TV por assinatura e luz, veem o orçamento doméstico ser reduzido pelo gasto extra. Corre-se, pois, o risco de que esta política tenha como trade-off o empobrecimento da população, enquanto o governo tem como meta a redução da pobreza.

A expansão de mercado, propiciada pela maior inserção do Estado, permite que cheguem alguns benefícios, como serviços de melhor qualidade, diversidade na oferta, conhecimento, oportunidades de fontes de renda e de capacitação. Assim, aqueles que têm mais capacidade de aproveitar a oportunidade, de lucrar, são beneficiados pela nova realidade, enquanto outros tantos vivem na insegurança. Neste sentido, a ideia de uma sociabilidade comunitária é, de certa forma, corroída pelo individualismo que o mercado provoca, cada um tentando garantir o seu quinhão. A maior entrada do mercado provoca disputas e prevalência de interesses pessoais, pois ele não atua de forma especificamente solidária. Apesar das ações de responsabilidade social que estão ocorrendo e das muitas ações de diferentes órgãos públicos, o propalado imaginário do jovem empreendedor em substituição ao do traficante poderoso envolve um elevado grau de ilusão, já que poucos possuem habilidades, ou terão oportunidades de atingir este ideal.

Enquanto alguns empreendedores aproveitam o aumento do turismo e da circulação de pessoas de maior poder aquisitivo para desenvolver iniciativas lucrativas de lazer, muitos moradores sentem que o espaço de lazer foi restringido, pois a quadra da escola de samba passou a abrigar festas caras, a Laje do Michael Jackson recebe frequentadores da rua para evento de samba, os preços praticados pelos bares aumentaram, ou seja, há um processo de mercantilização dos espaços sociais que segrega a população favelada dentro da própria comunidade.

Indubitavelmente, a população que ali reside percebe que a segurança física proporcionada pela presença do policiamento comunitário ostensivo viabiliza a entrada de outras ações de cunho social e de serviços públicos, bem como de novos interesses. Os moradores, em sua maioria, sentem mais segurança e percebem que, por meio dela, o Santa Marta ganhou visibilidade na mídia e perante a cidade. Contudo, nem todos terão condições de arcar com o preço da paz, o que gera insegurança. Aqueles que não conseguirem agarrar as oportunidades que têm surgido e que não têm condições de arcar com o aumento do custo de vida, possivelmente reduzirão o padrão de vida ou terão que sair da 
comunidade para locais mais afastados. O possível processo de gentrificação das zonas pacificadas adiará a solução dos problemas habitacionais e urbanos ao varrer a pobreza para áreas afastadas da cidade, onde há escassez de transporte público, de hospitais e escolas, além de outros serviços públicos.

O aumento do custo de vida na comunidade significa algo além do empobrecimento, pois a privação relativa de rendas pode resultar em privação absoluta de capacidades. Participar da vida da comunidade, em sentido amplo, está associado às exigências contextuais, que são cada vez mais rigorosas. Apesar de a grande maioria dos moradores ter sentido o impacto da cobrança de luz em seus orçamentos e o empobrecimento que o novo custo tem gerado, a política de regulação da Aneel demonstra a importância que este tipo de atuação estatal tem quando a questão é proteger os mais vulneráveis. Ademais, os efeitos da regulação não se restringem aos mais pobres, pois promove um bem público ao reduzir o desperdício, as disparidades e a poluição. Há neste fato, portanto, sinergia entre mercado, Estado e sociedade.

A chegada de diferentes projetos de capacitação à comunidade nesse período de rearticulação entre poder público, empresariado e a própria comunidade é percebido por alguns moradores como uma ampliação das oportunidades. Contudo, outros questionam o fato de elas estarem limitadas a subempregos e afirmam que não atendem aos anseios dos moradores, em especial aos dos jovens, grupo que se supõe mais vulnerável à influência dos traficantes.

Ademais, há grande preocupação quanto à sustentabilidade do projeto UPP, que, para alguns moradores, tem seu fim marcado para após os jogos olímpicos de 2016, que serão realizados na cidade. Tal preocupação leva-os a agir com prudência quanto às associações que fazem e quanto ao que falam, pois se sentem em um terreno ainda minado. Chega ao ponto de que aqueles que obtiveram sucesso empresarial com a chegada da UPP pensarem na necessidade de sair do morro caso o projeto chegue ao fim, devido ao medo de represálias pelo seu alinhamento às forças dominantes na situação atual.

A história nos mostra que o Estado tem papel primordial na compatibilização entre mercado e a segurança do cidadão visando o enriquecimento da vida civilizada com a redução do risco e da insegurança. Sem proteção e regulação estatal, os moradores da favela veem os direitos de cidadania ameaçados pela crescente especulação mercadológica e 
imobiliária, além de sofrerem o empobrecimento causado pelo aumento do custo de vida. Temem que isto resulte em um processo de remoção branca e começam a se organizar para fazer frente às políticas urbanas que não foram acordadas com a comunidade. A mobilização em torno da maior transparência das políticas e na regulação do mercado vem sendo demandada pela comunidade, cujo histórico de lutas para conquistar os benefícios mínimos da vida urbana, produziu atores respeitados dentro da favela.

Estes realizam trabalho de conscientização quanto à clientela que os empreendedores locais buscam atender, ou seja, moradores ou visitantes; convocam reuniões para discutir com a comunidade preocupações comuns; e reivindicam ativamente maior regulação e proteção do Estado, tendo em conta que a condição de cidadania não pode desconhecer as enormes desigualdades existentes entre a população da favela e os moradores do bairro no seu entorno. Igualar seus deveres de consumidores é visto como uma "cidadania de exceção", já que não desfrutam no morro dos bens públicos que são oferecidos pelo Estado à população do asfalto.

O medo da exclusão, sentimento fortemente presente na favela Santa Marta atualmente, tem a ver, em grande parte, com as demandas de proteção contra os avanços desregulados do mercado. A sensação de que a comunidade está sendo explorada economicamente e que está à mercê da insegurança e da especulação, sem que seus moradores tenham uma proteção estatal eficaz, gera grandes inseguranças. O risco atrelado a esse movimento está no fato de que tal exploração é socialmente aceita e até estimulada, eclipsando seus efeitos deletérios.

A importância destes resultados está em mostrar que há uma demanda cidadã para que o poder público utilize os instrumentos de regulação e de proteção social para evitar que os interesses comerciais se sobreponham aos interesses sociais, defendidos durante toda a história de resistência e construção de uma identidade própria desta comunidade. A disjuntiva entre o domínio do tráfico ou a paz da UPP tende a colocar os moradores da favela sem a liberdade de escolha de suas preferências, desconhecendo, ademais, as enormes desigualdades existentes na distribuição de recursos e acesso aos bens públicos que persistem na favela e na relação com seu entorno. Preocupante é que a favela tenha se tornado, em si mesma, uma mercadoria, desconhecendo a cidadania e a sociabilidade ali existentes, cuja memória os moradores insistem 
em preservar para garantir sua identidade e evitar que sejam assimilados como meros consumidores em um tecido urbano revigorado pelo mercado.

Na ausência de liberdade e igualdade, que só poderão ser garantidas por uma presença estatal cujas políticas públicas reconheçam a necessidade de equacionar de forma favorável à comunidade sua nova inserção urbana e social, o risco de que sejam tratados como meros consumidores é iminente. Assim, com o mercado subindo a favela como fruto da ação estatal, o que se coloca no cenário é a demanda de que a cidadania seja também garantida pelas políticas públicas. Se isto não acontecer, a subida do mercado ao morro pode vir a representar a descida da cidadania, com a expulsão da população favelada para novas áreas longínquas e desprovidas de serviços na periferia urbana. Se a equação equilibrada entre Estado, Mercado e Comunidade foi historicamente possível, esta questão está, hoje, na nossa agenda pública e requer uma resposta que preserve todos seus componentes. A condição de cidadania tem como pressuposto a presença do Estado como garantia da ordem policial e jurídica, mas seu exercício só se efetivará em condições de expansão das capacidades de forma a desenvolver as potencialidades individuais. Isto requer o reconhecimento das desigualdades de acesso da população aos bens públicos e proteção diferencial contra uma mera inserção igualitária no mercado de consumo. Se não for assim, o mesmo movimento visto como sucesso da política de pacificação, medida pela subida do mercado ao morro, poderá indicar seu fracasso, com a consequente descida da cidadania.

(Recebido para publicação em janeiro de 2013)

(Reapresentado em junho de 2013)

(Aprovado para publicação em agosto de 2013) 


\section{NOTAS}

1. Como o IETS (Instituto de Estudos do Trabalho e Sociedade), e a Casa das Garças Instituto de Estudos de Política Econômica.

2. Há polêmica em torno do nome e de qual vem a ser sua origem, inclusive entre os próprios moradores. Segundo alguns, uma imagem de Santa Marta foi colocada, ainda na década de 1920, no alto do morro por uma moradora. Como o local se tornou lugar de celebração religiosa, padre Velloso, do Colégio Santo Inácio e figura importante para a comunidade, optou por construir uma pequena capela para abrigar a imagem (Cunha e Mello, 2011). Outros, no entanto, afirmam que o nome do local se deve à sua antiga proprietária, que permitiu que aquelas pessoas ali vivessem e foi homenageada por elas ao darem seu nome, Dona Marta, ao morro. A confusão ficou mais marcante quando, na década de 1980, a mídia passou a se referir à comunidade como Dona Marta, nome do morro no qual se encontra e do mirante localizado no pico. De acordo com relatos de moradores, os evangélicos se apropriaram do nome e passou a haver uma disputa simbólica em torno dele. Apesar do Decreto de 13 de novembro de 2007, do então prefeito César Maia, fixar o nome Dona Marta para o morro (acidente geográfico) eSanta Marta para a comunidade, ainda há troca de nomes tanto pela mídia como até mesmo em documentos produzidos por órgãos públicos. A favela Santa Marta está localizada no morro Dona Marta, no bairro de Botafogo, Zona Sul da cidade do Rio de Janeiro, em uma área de $54.692 \mathrm{~m}^{2}$. Sua expansão está hoje limitada, ao lado direito, pelo plano inclinado e, ao lado esquerdo, por um muro, que separa a favela do terreno onde se encontra a sede da Prefeitura, construído em 2009, sob o argumento de que a intenção era proteger a vegetação nativa remanescente.

3. De acordo com o Censo de 2010, o Santa Marta possui 3.913 habitantes. Contudo, com a população do asfalto no trecho contíguo à favela e na área da UPP, também conhecido como franja, o número de pessoas se aproxima de cinco mil.

4. Apesar de relatos etnográficos apontarem grande dificuldade na abordagem de possíveis entrevistados dentro do Santa Marta, deparamo-nos com somente uma resistência, qual seja, a de um famoso empreendedor local, do qual tomamos conhecimento por meio de reportagens. Dono de uma barbearia e de cinco imóveis no espaço comercial mais privilegiado na comunidade, a Praça Cantão, os quais costuma alugar para moradia ou para empreendimentos comerciais, que inclui o imóvel onde foi instalada uma miniloja da rede Casa \& Vídeo, foi apelidado de “Eike Batista do Santa Marta" por uma reportagem de revista, fazendo referência ao bem-sucedido empresário brasileiro. Ao abordarmos o famoso comerciante, ele argumentou que já estava cansado de dar entrevistas e que havia passado a cobrar por elas. Esta foi, portanto, a única resistência que encontramos nas abordagens para as entrevistas.

5. Grupo formado por lideranças e moradores que começou com a criação de um jornal comunitário, em 1976, e cresceu ao se engajar em atividades de mutirão e mobilização.

6. Remoção branca refere-se à criação de condições que impedem a continuidade dos moradores no local, como por exemplo, a cobrança de impostos ou especulação imobiliária.

7. A coordenadora de programas do Sebrae-RJ em comunidades pacificadas, Carla Teixeira, afirma faltarem dados precisos sobre o empreendedorismo nas favelas. Uma

DADOS - Revista de Ciências Sociais, Rio de Janeiro, vol. 56, 꾸 3, 2013 


\section{Sabrina Ost e Sonia Fleury}

pesquisa encomendada pelo Sebrae ao IETS pretende detalhar as características dos negócios nesses locais.

8. O teto citado foi retirado em 31 de dezembro de 2011. Portanto, a partir de fevereiro de 2012, os moradores do Santa Marta passaram a pagar integralmente pela energia consumida.

9. Fundação de Apoio à Escola Técnica do Estado do Rio de Janeiro. Criada em 1997, está vinculada à Secretaria de Estado de Ciência e Tecnologia (SECT). Oferece educação profissional gratuita, em diversos níveis de ensino.

10. Laje com a estátua do cantor, celebrando o fato de que ali ele gravara um vídeo para lançamento de seu disco.

11. No original, gentrification. A expressão da língua inglesa foi usada pela primeira vez pela socióloga inglesa Ruth Glass, em 1964, ao analisar as transformações imobiliárias londrinas. Gentry significa “bem nascidos". 


\section{REFERÊNCIAS BIBLIOGRÁFICAS}

ANEEL (Agência Nacional de Energia Elétrica). (2008), Manual para Elaboração do Programa de Eficiência Energética. Brasília, Aneel.

BANCO MUNDIAL. (2013), O Retorno do Estado às Favelas do Rio de Janeiro: Uma Análise da Transformação do Dia a Dia das Comunidades após o Processo de Pacificação das UPPs.

BARDIN, Laurence. (2006), Análise de Conteúdo. 4a ed. Lisboa, Edições 70.

BAYLEY, Kenneth. (1994), Methods of Social Research. 4a ed. New York, The Free Press.

BOBBIO, Norberto. (1993), A Era dos Direitos. Rio de Janeiro, Editora Campus.

BURGOS, Marcelo Baumann. (2005), “Cidade, Territórios e Cidadania”. DADOS, vol. 48, no 1, pp. 189-222.

CALDERÓN, Fernando. (1995), "Governance, Competitiveness and Social Integration". CEPAL Review, no 57, pp. 45-56.

CARRIÓN, Fernando. (2007), "El Desafío Político de Gobernar la Ciudad". Nueva Sociedad, no 212, pp. 36-52.

CUNHA, Neiva Vieira da e MELLO, Marco Antonio da Silva. (2011), “Novos Conflitos na Cidade: AUPP e o Processo de Urbanização na Favela". Dilemas: Revista de Estudos de Conflito e Controle Social, vol. 4, no 3, pp. 371-401.

EVANS, Peter. (1996), “Government Action, Social Capital and Development: Reviewing the Evidence on Synergy". World Development, vol. 24, no 6, pp. 1119-1132.

FERREIRA, Sergio Guimarães. (2011), “Segurança Pública nas Grandes Cidades”, in E. Bacha e S. Schwartzman (orgs.), Brasil: A Nova Agenda Social. Rio de Janeiro, LTC, pp. 287-318.

FICHER, Brotwyn M. (2008), A Poverty of Rights. Citizenship and Inequality in Twenty-Century Rio de Janeiro. Stanford, University of California Press.

FLEURY, Sonia. (2003), “La Expansión de la Ciudadanía”, in M. Bonilla (ed.), Inclusión Social y Nueva Ciudadanía: Condiciones para la Convivencia y Seguridad Democráticas. Memórias. Colombia, Ed. Universidad Javeriana, pp. 167-194.

. (2004), “Construcción de Ciudadanía en Entornos de Desigualdad”, in C. Binetti e F. Carrillo (eds.), ¿Democracia con Desigualdad?. Washington, DC, BID, pp.81-114.

FRASER, Nancy. (2003), “Social Justice and the Age of Identity Politics: Redistribution, Recognition, and Participation", in N. Fraser e A. Honneth (orgs.), Redistribution or Recognition?. London, Verso, pp. 7-109.

IETS (Instituto de Estudos do Trabalho e Sociedade). (2010), Primeira Análise da Pesquisa Socioeconômica e do Perfil de Gestão de Risco das Populações dos Morros Santa Marta, Babilônia e Chapéu Mangueira. Análise Preliminar. Rio de Janeiro, IETS.

LECHNER, Norbert. (2000), “Desafíos de un Desarrollo Humano: Individualización y Capital Social". Instituciones y Desarrollo, no 7, pp. 7-34.

LINDBLOM, Charles E. (1982), “The Market as Prison”. The Journal of Politics, vol. 44, pp. 324-336.

DADOS - Revista de Ciências Sociais, Rio de Janeiro, vol. 56, nº 3, 2013 


\section{Sabrina Ost e Sonia Fleury}

MACHADO DA SILVA, Luiz Antonio. (2010), “Violência Urbana, Segurança Pública e Favelas-O Caso do Rio de Janeiro Atual". Cadernos CRH, vol. 23, no59, pp. 283-300.

MARSHALL, Thomas H. (1967), Cidadania, classe social e status. Rio de Janeiro, Zahar Editores.

MATTAR, Flávia; CHEQUER, Jamile e DIAS, Mariana. (2010), “UPP: Tecendo Discursos". Democracia Viva, no 45, pp. 72-81.

NERI, Marcelo Côrtes (org.). (2010), The New Middle Class in Brazil: The Bright Side of the Poor. Rio de Janeiro, FGV/IBRE, CPS.

O GLOBO. (2012), “LIGHT já reduziu em 90\% 'gatos' de energia em cinco comunidades com UPPs". O Globo, 03/01/2012. Disponível em <http://oglobo.globo.com/ rio/light-ja-reduziu-em-90-gatos-de-energia-em-cinco-comunidades-comupps-3555758>. Acesso em 3/1/2012.

OFFE, Claus. (1998), The Present Historical Transition and some Basic Design Options for Societal Institutions. Brasília, MARE.

PANDOLFI, Dulce C. e GRYNSZPAN, Mario. (2003), A Favela Fala: Depoimentos ao CPDOC. Rio de Janeiro, FGV Editora, pp. 298-360.

PERLMAN, Janice. (1977), O Mito da Marginalidade. Rio de Janeiro, Paz e Terra.

POLANYI, Karl. (1980), A Grande Transformação. 2a ed. Rio de Janeiro, Campus.

RIBEIRO, Luiz Cesar Queiroz e LAGO, Luciana. (2001), “A Oposição Favela-Bairro no Espaço Social do Rio de Janeiro”. São Paulo em Perspectiva, vol. 15, no 1, pp. 144-154.

RODRIGUES, Maria Cecília P. (2004), Ação Social das Empresas Privadas: Uma Metodologia para Avaliação de Resultados. Tese de Doutorado em Administração. Rio de Janeiro, EBAPE/FGV.

SEN, Amartya. (2000), Desenvolvimento como Liberdade. São Paulo, Companhia das Letras.

SMITH, Neil. (1979), "Toward a Theory of Gentrification: A Back to the City Movement by Capital, not People". Journal of the American Planning Association, no 45, pp. 538-547.

(2002), “New Globalism, New Urbanism: Gentrification as Global Urban Strategy". Antipode, vol. 34, no 3, pp. 427-450.

TERRA, Thiago. (2010). "Sky Entra em Favelas para Ampliar Atuação no Rio". Exame.com, 15/09/2010. Disponível em <http: / / exame.abril.com.br/ marketing/noticias/sky-entra-favelas-ampliar-atuacao-rio-596495>. Acesso em 15/09/2010.

VAINER, Carlos. (2011), "Cidade de Exceção: Reflexões a Partir do Rio de Janeiro”. Anais do XIV Encontro Nacional da Associação Nacional de Planejamento Urbano (ANPUR), vol. 14.

VALLADARES, Licia. (2000), “A Gênese da Favela Carioca”. Revista Brasileira de Ciências Sociais, vol.15, no 44, pp.5-34.

YOUNG, Iris M. (2000), Inclusion and Democracy. Oxford, Oxford University Press.

ZALUAR, Alba e ALVITO, Marcos (orgs.). (2006), Um Século de Favela. 5a ed. Rio de Janeiro, FGV Editora.

ZELIZER, Viviana. (2009), “Dualidades Perigosas”. MANA, vol. 15, no 1, pp. 237-256. 


\author{
ABSTRACT \\ The Market Goes to the Favela. Do Citizens Come Back? Socioeconomic \\ Effects of Pacification of the Santa Marta Favela
}

This study in the Santa Marta favela following installation of the Peacekeeping Police Unit (UPP) aimed to analyze the market's dynamics and the effects on residents' lives. The study involved direct observations and interviews with residents and individuals involved in business activities. Data were grouped according to market expansion through new companies, business diversification, and the formal incorporation of services. The discourses on social responsibility and increased capacities were also analyzed. The data suggest that the state's presence was a prerequisite for market expansion in the territory, even while the use of public spaces by residents and local businesses are in decline. The increasing cost of living in the area generates insecurity due to the threat of white gentrification. The purported social inclusion through the market clashes with the intended expansion of citizenship, with the state failing to provide minimum safeguards.

Key words: state; market; community; citizenship; favela; Santa Marta; public policy; Peacekeeping Police Unit (UPP)

\title{
RÉSUMÉ
}

Le Monde des Affaires Gravit la Favela. La Citoyenneté la Descend? Effets Socioéconomiques de la Pacification dans la Favela Santa Marta

Le but de l'étude sur la favela Santa Marta après la mise en place de l'Unité de Police Pacificatrice (UPP) consistait dans l'analyse de la dynamique du marché et de ses effets sur la vie des habitants. On a effectué des observations et entretiens avec les habitants et les acteurs engagés dans des activités entrepreneuriales. Les données ont été rassemblées en fonction de l'expansion du marché reflétée par de nouvelles entreprises, la diversification des affaires et la formalisation des services. On a aussi pris en compte les discours sur la responsabilité sociale et une extension des qualifications. Selon les données, la présence de l'État a été une condition préalable à l'expansion du marché dans cette zone, tandis que l'usage des espaces publics par les habitants et les affaires locales ont décliné. L'augmentation du coût de la vie provoque de l'insécurité face à un prévisible "délogement" en douceur. La soi-disant inclusion par le marché entre en contradiction avec la prétention d'élargissement de la citoyenneté, dans des conditions où des garanties minimes ne sont pas assurées par l'État.

Mots-clés: État; marché; communauté; citoyenneté; favela; Santa Marta; politiques publiques; Unité de Police Pacificatrice (UPP) 